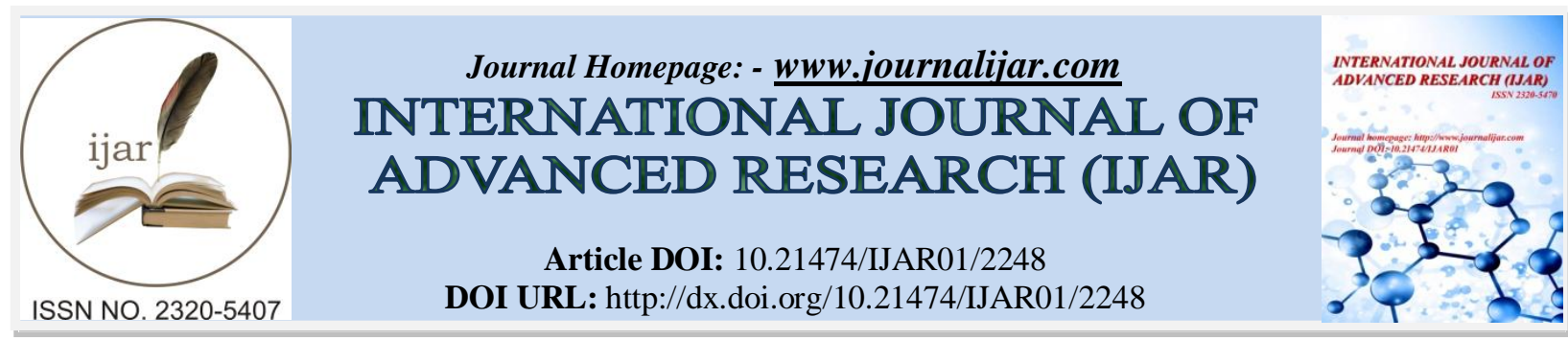

RESEARCH ARTICLE

\title{
IDENTIFICATION OF A SET OF APPROPRIATE CRITICAL SUCCESS FACTORS (CSFS) FOR SUCCESSFUL TQM IMPLEMENTATION IN CONSTRUCTION, AND OTHER INDUSTRIES.
}

Behnam Neyestani ${ }^{1}$ and Joseph Berlin P. Juanzon ${ }^{2}$.

1. Ph.D. Candidate, Department of Civil Engineering, De La Salle University, Manila, Philippines.

2. Assistant Professor, Department of Civil Engineering, De La Salle University, Manila, Philippines.

\section{Manuscript Info}

Manuscript History

Received: 29 September 2016

Final Accepted: 30 October 2016

Published: November 2016

Key words:-

TQM; CSFs;

Implementation; Framework;

Construction Industry.

\section{Abstract}

Total quality management (TQM) is a management philosophy that emphasizes on non-stop quality improvement within all aspects of the organizations. Its main aims are to satisfy customers and survive in the market. Thus, it is very vital to specify the factors that cause implementing TQM successfully. Specially, the identification of the TQM critical success factors (CSFs) is more important in the construction firms than other industries, because the majority of construction organizations are confusing related to TQM CSFs, and often they do not develop a proper framework with right and essential factors for TQM implementation. Numerous studies showed construction companies usually fail to implement TQM and achieve performance excellence at project and enterprise levels. The main purpose of this study is to determine these factors as critical success factors of TQM implementation in construction industry. For this aim, the study carried out an extensive literature review to specify the most frequently used CSFs from TQM frameworks of 37 empirical studies in different industries, in order to propose a set of appropriate TQM CSFs. So, Pareto analysis was employed to analyze comprehensively the 37 TQM frameworks. Finally, the findings of this study revealed the seven CSFs, which are as most vital elements in developing an effective framework for successful TQM implementation in construction industry.

Copy Right, IJAR, 2016,. All rights reserved.

\section{Introduction:-}

With the turn of the new millennium, global competition has increased. This competitive pressure motivates the companies' management to verify their "business strategies and practices", in order to survive in the market (Mahmood et al., 2015). One of the key elements of the competitiveness is "quality" as the results of organizational performance, which has a significant role in the success of projects in modern construction (Kheni and Ackon, 2015; Ashokkumar, 2014). There are different methodologies and approaches that the construction companies can adopt to improve continuously the quality and performance of their projects. Doubtlessly, Total Quality Management (TQM) is the most effective quality management program among them. TQM is a holistic quality management approach that proved its capability to both practitioners and scholars (Martinez-Costa et al., 2008; Shafiq et al., 2014).

Corresponding Author:- Behnam Neyestani,

Address:- Department of Civil Engineering, De La Salle University, Manila, Philippines. 
Historically, TQM was first revealed by the contribution of quality gurus, such as Deming, Juran in Japan after Second World War. Then Crosby, Feigenbaum, Ishikawa, and others had the significant roles to develop this powerful management method. During the period 1980s to 1990s, many national and international quality awards (QAs) have been established to provide guidelines for implementing TQM framework in practice. The most widely known of the quality awards (QAs) are the Deming Prize in Japan, the MBNQA in the USA, and the EQA in EU. Nowadays, the success of the TQM philosophy in manufacturing and other industries is forcing construction firms to use TQM for improving quality and performance of the projects (Metri, 2005). Also, a large number of research papers has been indicated that TQM implementation can be able to promote "customer satisfaction", "quality products", and "market share" in construction firms (Farooqui and Ahmed, 2009).

Some studies reported that the implementation of TQM practices is very difficult in construction organizations because of "a lack of standardization" and "many parties" (Hoonakker et al., 2010). Thus, the identification of "critical factors" that cause the success in implementing TQM is extremely vital in the organizations (Hietschold et al., 2014; Kalpande et al., 2012). In other words, "the construction companies need to understand the TQM CSFs for the successful implementation of TQM" (Metri, 2005, p. 62). Forbes and Ahmed (2011) justified because the contractors and managers are very busy to explore and determine critical success factors (CSFs) in the construction firms. Therefore, the best way is to select CSFs from the criteria of quality awards, in order to achieve a high level of quality in construction processes. While Oakland (2003) as one of the influential TQM gurus in $21^{\text {th }}$ Century, stressed that formal TQM like MBNQA and EQA give only broad guidelines, and their criteria often promote the elements that do not seem to provide any "business value" for an organization. Consequently, it is necessary that the organizations construct their own TQM frameworks based on their needs. This aim can be done by adopting suitable TQM practices (e.g. process management, leadership, etc.) through previous empirical studies, with the aim of implementing TQM successfully (Hietschold et al., 2014; Kalpande et al., 2012). Interestingly "CSFs identify the issues that determine an organization's health and vitality" (Parmenter, 2007, p. 23). In fact, many studies revealed that construction firms are often unsuccessful in adopting suitable TQM practices (CSFs) within their TQM implementation frameworks (Delgado-Hernandez and Aspinwall, 2008). As stated by Metri (2005, p. 62), there is a "pressing need" to identify TQM CSFs in construction organizations.

In the academic aspect, Karuppusami and Gandhinathan (2006) stated researchers should understand the importance of CSFs as "vital few" CSFs to conduct their researches. This can be a good way to develop "reliable instruments", and investigate the effects of TQM on the organizations. Amazingly, although identifying TQM CSFs is an important issue in implementing TQM in the construction industry, but literature survey showed that a few study just carried out to determine TQM CSFs into construction field. Some studies were proven that critical factors of successful TQM implementation are the same in all sectors, because the business and behavior issues are tightly related to TQM CSFs, not the context of business and sector (Delgado-Hernandez and Aspinwall, 2008; Arumugam et al., 2011; Cheng and Liu, 2007). Accordingly, it seems that the best solution for this problem in construction industry is to identify the most frequently used TQM practices by scholars in different industries from past studies. The main purpose of this paper is to provide a comprehensive study on the TQM critical success factors (CSFs) from existing literature, and likewise evaluate different TQM models that formulated by scholars in different sectors and countries, in order to determine and propose a set of TQM CSFs in constructing an appropriate TQM implementation framework for construction firms at project and enterprise levels.

\section{Literature Review:-}

Although "the definitions of TQM has been debated for many years by quality management researchers" (Sila and Ebrahimpour, 2003, p. 235). But the previous definitions of TQM mostly have the same view on the scope of this quality management program. Initially, both academics and practitioners considered it as a management approach that improves the products and services quality continuously through the production process for satisfying customers. Burli et al. (2012) and Martinez-Costa et al. (2008) defined TQM as a "systematic quality practices" for the management of the company to generate desirable change in the performance with the aim of promoting "quality, productivity, customer's satisfaction and profitability". TQM practices are able to generate effective processes that bring consistency to improve performance and business processes for satisfying customers (Al-Otaibi et al., 2015). Many empirical studies have indicated the significant correlation between the vital TQM practices (CSFs) and quality performance in the organizations (Talib et al., 2010). Consequently, it is very essential to specify and consider the practices, or elements that are critical to implement TQM. In other words, the CSFs are the "best practices", "enablers", and vital factors that contribute to the success of TQM implementation. These factors are 
now as an outstanding specification of the most of the successful businesses world (Hietschold et al., 2014; Irfan and Kee, 2013).

TQM CSFs can also be defined as "the behavioral aspects of management styles" or the human factors (activities), which should be practiced to achieve quality management goals and organizational objectives (Arumugam et al., 2011). Kaur and Sharma (2014) argued that CSFs of TQM can be demonstrated as "finest approaches" adopted in all key activities of every kind of the business. But there is no generic set of CSFs as they vary from organization to organization and manager to manager as it depends on where the organization is and where it wants to be (SantosVijande and Alvarez-Gonzalez, 2007; Arshida and Agil, 2013). Similarly, some surveys showed there are differences between the critical success factors of TQM practices in different countries, for example, USA and Mexico. In both countries, social responsibilities and supplier quality were meaningfully different, because of possessing different culture. But customer focus and satisfaction were similar between two countries as most important factor in business and TQM. However, the differences in the "degree of TQM implementation" in different countries exist (Zakuan et al., 2012; Al-Otaibi et al., 2015).

Oakland (2003) stated the key to strategic planning and goal development is just to identify a set of appropriate TQM practices. He stressed exceedingly that the positive changes in improving quality can be happened by the emphasis of using critical TQM practices (factors), instead of focusing on just formal structures of TQM in the organizations. In construction, companies also need study and identify vital TQM practices in implementing TQM successfully. Delgado-Hernandez and Aspinwall (2008) and Metri (2005) argued that construction companies need to select and adopt a set of TQM CSFs from TQM studies in different industries, the especially manufacturing sector as "survival factors, or indicators of corporate quality". But construction and manufacturing are not quite the same, and there are many differences between them. So, there is a significant question related this issue, can extract TQM CSFs of manufacturing, or service sectors be suitable and fitted for developing an effective TQM model in construction organizations? Surprisingly, the results of some studies have justified, all industries recognized the same CSFs for TQM implementation. Because TQM CSFs are more depended upon "working environments", "work attitudes and leadership styles", which influence the implementation of the TQM approach than the context of business. Thus, it is important that companies understand their organizational culture profiles and environments (Cheng and Liu, 2007). As depicted in Figure 1, Hietschold et al. (2014) interpreted that the research field on TQM originates from the contribution of quality gurus as well as quality award criteria in the 1980s. Until the end of the 1990 s, the vast majority of the literature on quality management was based on "case studies", "descriptive and conceptual articles" with "few exceptions of empirical studies" in determining TQM CSFs. However, the empirical studies have become as most important sources to specify a set of TQM CSFs, when Saraph et al. were first introduced and "operationalized" these factors from empirical studies in 1989. The scholars and practitioners still use empirical studies on TQM for identifying their TQM CSFs (Talib et al., 2010).

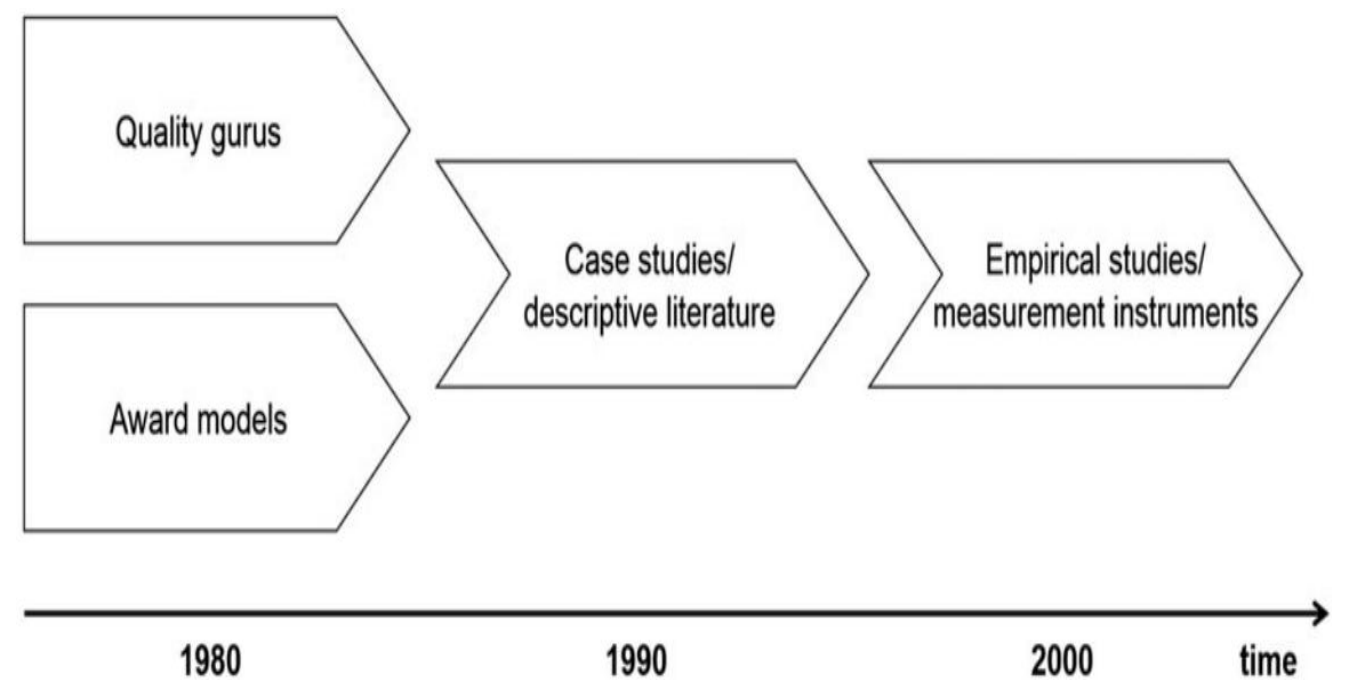

Figure 1:- Illustration of the CSF literature development (Hietschold et al., 2014, p. 6256) 


\section{Methodology:-}

The general objective of this study is to investigate and suggest a set of TQM CSFs for developing a poweful TQM framework at project and enterprise levels in the construction industry. For this aim, the methodology of current study designed based on an extensive literature review on empirical studies concerning CSFs of TQM implementation, or quality management practices from different industries in various countries. Therefore, a comprehensive search was carried out using online databases to find empirical studies, which published in English and referred journals in the period from 2004 to 2015. These databases were namely; Elsevier Science, Google Scholar, Emerald (MCB) Database, EBSCO, ProQuest and Anbar International Management. Furthermore, the study was being searched based on the 15 phrases, or keywords, which Sila and Ebrahimpour (2003, p. 239) determined in the literature for interpreting "TQM-related factors, and critical practices in implementing successful TQM. These keywords are namely: "total quality management, quality management, strategic quality management, total quality, total quality improvement, total quality control, business excellence, performance excellence, quality excellence, best practices, world-class manufacturing, continuous improvement, continuous quality improvement, quality improvement, quality assurance".

In this study, the review of the literature from online databases yielded 258 studies that the majority of the studies within the literature were before 2004. Thus, the researcher identified the only 72 studies that published between 2004 and 2015. In next step, the content analysis was used by the researcher to review and examine qualitatively/subjectively papers ( 72 articles), in order to ensure that their contents are relevant to CSFs of TQM implementation, or quality management practices as well as the objective of this study. Accordingly, a total of 37 TQM studies selected and finalized for further study as illustrated in Table 2. Finally, extracted data from literature review was categorized, coded and entered into Microsoft Excel for data analysis. For data analysis, Pareto analysis was employed as most suitable method in identifying TQM "CSFs-vital few" (80 percent) and "CSFs-useful many" (20 percent) of existing TQM practices from these 37 studies. According to Talib et al (2010, p. 158), "Pareto analysis is a statistical technique in decision making that should be used for the selection of a limited number of tasks that produce significant overall effect. It is one of the most commonly used, and easy to implement method". Pareto analysis uses frequency distribution as one of the techniques of exploratory data analysis that is often used to interpret data. It arranges and presents elements and data from highest to lowest frequency of occurrences respectively, which can assist this research to identify easily the most important factors to implement successful TQM in the construction industry from previous TQM studies in different industries.

\section{Results and Discussion:-}

As mentioned previously, the literature review unearthed 37 studies that were fitted and suitable to use for this research, by reviewing these papers, it was revealed that the majority of the studies conducted by researchers in manufacturing and service sectors with a percentage of $78.4 \%$, and the only $21.6 \%$ of the articles belonged to construction area. Furthermore, these TQM studies were carried out in three periodical stages (the period from 2004 to 2007, 2008 to 2011, and 2012 to 2015). Table 1 indicated the majority of TQM papers that are about 21 studies with a percentage of $56.8 \%$ of the total articles were performed by scholars between 2012 and 2015 .

Table 1:- Summary of the specifications of selected articles in this study

\begin{tabular}{|l|c|c|c|}
\hline Scope & $2004-2007$ & $2008-2011$ & $2012-2015$ \\
\hline Manufacturing or/and Service sector/s & $4(10.8 \%)$ & $9(24.3 \%)$ & $16(43.3 \%)$ \\
\hline Construction & $1(2.7 \%)$ & $2(5.4 \%)$ & $5(13.5 \%)$ \\
\hline Total & $5(13.5 \%)$ & $11(29.7 \%)$ & $21(56.8 \%)$ \\
\hline
\end{tabular}

Literature review was also presented the wide variety of TQM practices, or elements as critical success factors (CSFs), which used for formulating TQM implementation frameworks by the authors of empirical studies. Interestingly, more than $50 \mathrm{TQM}$ CSFs were derived and highlighted from reviewing theses 37 studies, which each of these TQM CSFs was relevant with a certain group of identified critical success factors, although they had different names and labels but their descriptions were similar. Thus, the content of extracted CSFs analyzed one by one carefully, and then TQM CSFs with similar concept identified and classified within a certain group under a title, for example, top management commitment, leadership, management support, executive commitment, senior executive involvement, quality leadership, top management involvement, top executive support were categorized under a label (Leadership). Consequently, based on this process, of approximately 50 initial TQM CSFs, about 22 
main factors were highlighted and indicated as TQM critical success factors (CSFs) of these empirical studies, and there is no similarity between the content of each of these 22 TQM CSFs and others, as illustrated in Table 2.

Table 2:- List of TQM critical success factors that derived from 37 papers

\begin{tabular}{|c|c|c|}
\hline No. & CSF & Author/s \\
\hline 1 & $\begin{array}{l}\text { Customer focus } \\
\text { (CF) }\end{array}$ & $\begin{array}{l}\text { Burli et al. (2012); Shafiq et al. (2014); Hassan et al. (2012); Fotopoulos et al. (2010); } \\
\text { Malik et al. (2010); Deepa (2014); Martinez-Costa et al. (2004); Martinez-Costa et al.( } \\
\text { 2008); Mahmood et al. (2015); Kaur and Sharma (2014); Herzallah et al. (2014); } \\
\text { Mehmood highlighted et al. (2014); Bigliardi and Galati (2014); Prajogo and Hong } \\
\text { (2008); Hassan et al. (2013); Koc (2011); Martinez-Costa et al. ( 2009); Kuo et al. } \\
\text { (2009); Tan et al. (2013); Alamri, et al (2014); Zakuan et al. (2012); Talavera (2005); } \\
\text { Arshida and Agil (2013); Arumugam et al. (2011); Irfan and Kee (2013); Mahboob et } \\
\text { al. (2015); Talib et al (2010); Karuppusami and Gandhinathan (2006); Kheni and } \\
\text { Ackon (2015); Saeed and Hasan (2012); Metri (2005); Al-Otaibi et al. (2015); Koh and } \\
\text { Low (2010). }\end{array}$ \\
\hline 2 & Leadership (L) & $\begin{array}{l}\text { Shafiq et al. (2014); Hassan et al. (2012); Malik et al. (2010); Deepa (2014); Santos- } \\
\text { Vijande and Alvarez-Gonzalez (2007); Martinez-Costa et al. ( 2004); Martinez-Costa } \\
\text { et al.( 2008); Mahmood et al. (2015); Kaur and Sharma (2014); Herzallah et al. (2014); } \\
\text { Mehmood et al. (2014); Prajogo and Hong (2008); Hassan et al. (2013); Gherbal et al. } \\
\text { (2012); Kheni and Ackon (2015); Saeed and Hasan (2012); Metri (2005); Al-Otaibi et } \\
\text { al. (2015); ALNasser et al. (2013); Delgado-Hernandez and Aspinwall (2008); Koh } \\
\text { and Low (2010); Koc (2011); Martinez-Costa et al. (2009); Kuo et al. (2009); Tan et } \\
\text { al. (2013); Alamri, et al (2014); Zakuan et al. (2012); Arshida and Agil } \\
\text { (2013);Mahboob et al. (2015); Arumugam et al. (2011); Irfan and Kee (2013); Talib et } \\
\text { al (2010); Karuppusami and Gandhinathan (2006). }\end{array}$ \\
\hline 3 & $\begin{array}{l}\text { Process } \\
\text { Management (PM) }\end{array}$ & $\begin{array}{l}\text { Burli et al. (2012); Shafiq et al. (2014); Hassan et al. (2012); Fotopoulos et al. (2010); } \\
\text { Kheni and Ackon (2015); Metri (2005); Al-Otaibi et al. (2015); Al-Nasser et al. } \\
\text { (2013); Delgado-Hernandez and Aspinwall (2008); Koh and Low (2010); Santos- } \\
\text { Vijande and Alvarez-Gonzalez (2007); Martinez-Costa et al. ( 2004); Martinez-Costa } \\
\text { et al.( 2008); Kaur and Sharma (2014); Herzallah et al. (2014); Bigliardi and Galati } \\
\text { (2014); Prajogo and Hong (2008); Koc (2011); Martinez-Costa et al. ( 2009); Kuo et } \\
\text { al. (2009); Tan et al. (2013); Alamri, et al (2014); Talavera (2005); Arumugam et al. } \\
\text { (2011); Hassan et al. (2013); Mahboob et al. (2015); Talib et al (2010); Karuppusami } \\
\text { and Gandhinathan (2006). }\end{array}$ \\
\hline 4 & $\begin{array}{l}\text { Supplier } \\
\text { management (SM) }\end{array}$ & $\begin{array}{l}\text { Burli et al. (2012); Shafiq et al. (2014); Malik et al. (2010); Deepa (2014); Santos- } \\
\text { Vijande and Alvarez-Gonzalez (2007); Martinez-Costa et al. (2004); Martinez-Costa et } \\
\text { al.( 2008); Kaur and Sharma (2014); Herzallah et al. (2014); Koc (2011); Martinez- } \\
\text { Costa et al. ( 2009); Alamri, et al (2014); Arshida and Agil (2013); Arumugam et al. } \\
\text { (2011); Kheni and Ackon (2015); Saeed and Hasan (2012); Metri (2005); Al-Otaibi et } \\
\text { al. (2015); Al-Nasser et al. (2013); Delgado-Hernandez and Aspinwall (2008); Koh } \\
\text { and Low (2010); Mahboob et al. (2015); Talib et al (2010); Karuppusami and } \\
\text { Gandhinathan (2006). }\end{array}$ \\
\hline 5 & $\begin{array}{l}\text { Employee } \\
\text { involvement (EI) }\end{array}$ & $\begin{array}{l}\text { Shafiq et al. (2014); Hassan et al. (2012); Gherbal et al. (2012); Saeed and Hasan } \\
\text { (2012); Kheni and Ackon (2015); Metri (2005); Al-Nasser et al. (2013); Al-Otaibi et } \\
\text { al. (2015); Fotopoulos et al. (2010); Malik et al. (2010); Mahmood et al. (2015); } \\
\text { Mehmood et al. (2014); Bigliardi and Galati (2014); Martinez-Costa et al. (2009); } \\
\text { Alamri, et al (2014); Zakuan et al. (2012); Talavera (2005); Arshida and Agil (2013); } \\
\text { Herzallah et al. (2014); Mahboob et al. (2015); Talib et al (2010); Karuppusami and } \\
\text { Gandhinathan (2006). }\end{array}$ \\
\hline 6 & $\begin{array}{l}\text { Information and } \\
\text { anaysis (IA) }\end{array}$ & $\begin{array}{l}\text { Hassan et al. (2012); Fotopoulos et al. (2010); Martinez-Costa et al. (2004); Martinez- } \\
\text { Costa et al.( 2008); Herzallah et al. (2014); Prajogo and Hong (2008); Hassan et al. } \\
\text { (2013); Koc (2011); Kaur and Sharma (2014); Martinez-Costa et al. (2009); Kuo et al. }\end{array}$ \\
\hline
\end{tabular}




\begin{tabular}{|c|c|c|}
\hline & & $\begin{array}{l}\text { (2009); Tan et al. (2013); Irfan and Kee (2013); (Mahboob et al., 2015); Metri (2005); } \\
\text { Al-Otaibi et al. (2015); Al-Nasser et al. (2013); Delgado-Hernandez and Aspinwall } \\
\text { (2008); Koh and Low (2010); Talib et al (2010); Karuppusami and Gandhinathan } \\
\text { (2006). }\end{array}$ \\
\hline 7 & $\begin{array}{l}\text { Education and } \\
\text { training (ET) }\end{array}$ & $\begin{array}{l}\text { Gherbal et al. (2012); Saeed and Hasan (2012); Metri (2005); Al-Otaibi et al. (2015); } \\
\text { Al-Nasser et al. (2013); Delgado-Hernandez and Aspinwall (2008); Koh and Low } \\
\text { (2010); Shafiq et al. (2014); Deepa (2014); Herzallah et al. (2014); Koc (2011); } \\
\text { Zakuan et al. (2012); Arshida and Agil (2013); Arumugam et al. (2011); Mahboob et } \\
\text { al. (2015); Talib et al (2010); Karuppusami and Gandhinathan (2006). }\end{array}$ \\
\hline 8 & $\begin{array}{l}\text { Continuous quality } \\
\text { improvement (CQI) }\end{array}$ & $\begin{array}{l}\text { Burli et al. (2012); Shafiq et al. (2014); Hassan et al. (2012); Deepa (2014); Mahmood } \\
\text { et al. (2015); Al-Otaibi et al. (2015); Delgado-Hernandez and Aspinwall (2008); Koh } \\
\text { and Low (2010); Mehmood et al. (2014); Zakuan et al. (2012); Talavera (2005); } \\
\text { Mahboob et al. (2015); Talib et al (2010). }\end{array}$ \\
\hline 9 & $\begin{array}{l}\text { Strategic quality } \\
\text { management (SQM) }\end{array}$ & $\begin{array}{l}\text { Santos-Vijande and Alvarez-Gonzalez (2007); Bigliardi and Galati (2014); Prajogo } \\
\text { and Hong (2008); Hassan et al. (2013); Kuo et al. (2009); Tan et al. (2013); Alamri, et } \\
\text { al (2014); Kaur and Sharma (2014); Arshida and Agil (2013); Mahboob et al. (2015); } \\
\text { Talib et al (2010); Al-Nasser et al. (2013); Metri (2005). }\end{array}$ \\
\hline 10 & $\begin{array}{l}\text { Human resource } \\
\text { management }(\mathrm{HRM})\end{array}$ & $\begin{array}{l}\text { Burli et al. (2012); Martinez-Costa et al. ( 2004); Martinez-Costa et al.( 2008); Santos- } \\
\text { Vijande and Alvarez-Gonzalez (2007); Prajogo and Hong (2008); Hassan et al. (2013); } \\
\text { Koc (2011); Metri (2005); Kuo et al. (2009); Tan et al. (2013); Mahboob et al. (2015); } \\
\text { Talib et al (2010); Karuppusami and Gandhinathan (2006); Koh and Low (2010). }\end{array}$ \\
\hline 11 & $\begin{array}{l}\text { Product and service } \\
\text { design (PSD) }\end{array}$ & $\begin{array}{l}\text { Martinez-Costa et al. ( 2004); Saeed and Hasan (2012); Metri (2005); Martinez-Costa } \\
\text { et al. ( 2008); Herzallah et al. (2014); Bigliardi and Galati (2014); Martinez-Costa et } \\
\text { al. ( 2009); Arumugam et al. (2011); Mahboob et al. (2015); Talib et al (2010); } \\
\text { Karuppusami and Gandhinathan (2006). }\end{array}$ \\
\hline 12 & Teamwork (T) & $\begin{array}{l}\text { Deepa (2014); Zakuan et al. (2012); Arumugam et al. (2011); Talib et al (2010); } \\
\text { Gherbal et al. (2012); Kheni and Ackon (2015); Saeed and Hasan (2012). }\end{array}$ \\
\hline 13 & Communication $(\mathrm{C})$ & $\begin{array}{l}\text { Gherbal et al. (2012); Kheni and Ackon (2015); Shafiq et al. (2014); Bigliardi and } \\
\text { Galati (2014); Zakuan et al. (2012); Mahboob et al. (2015); Talib et al (2010). }\end{array}$ \\
\hline 14 & $\begin{array}{l}\text { Quality culture } \\
\text { (QC) }\end{array}$ & $\begin{array}{l}\text { Malik et al. (2010); Gherbal et al. (2012); Delgado-Hernandez and Aspinwall (2008); } \\
\text { Irfan and Kee (2013); Talib et al (2010). }\end{array}$ \\
\hline 15 & $\begin{array}{l}\text { Quality systems } \\
\text { (QS) }\end{array}$ & $\begin{array}{l}\text { Fotopoulos et al. (2010); Mahboob et al. (2015); Talib et al (2010); Karuppusami and } \\
\text { Gandhinathan (2006); Delgado-Hernandez and Aspinwall (2008). }\end{array}$ \\
\hline 16 & $\begin{array}{l}\text { Recognition and } \\
\text { reward }(\mathbf{R R})\end{array}$ & $\begin{array}{l}\text { Hassan et al. (2012); Talavera (2005); Arshida and Agil (2013); Saeed and Hasan } \\
\text { (2012). }\end{array}$ \\
\hline 17 & Benchmarking (B) & Shafiq et al. (2014); Malik et al. (2010); Talib et al (2010). \\
\hline 18 & $\begin{array}{l}\text { Role of quality } \\
\text { department (RQD) }\end{array}$ & Fotopoulos et al. (2010); Talib et al (2010); Karuppusami and Gandhinathan (2006). \\
\hline 19 & $\begin{array}{l}\text { Fact-based } \\
\text { management }(\text { FBM) }\end{array}$ & Hassan et al. (2012); Talavera (2005). \\
\hline 20 & $\begin{array}{l}\text { Quality assurance } \\
\text { (QA) }\end{array}$ & Mahboob et al. (2015); Talib et al (2010). \\
\hline 21 & $\begin{array}{l}\text { Commitment to } \\
\text { quality (CQ) }\end{array}$ & Irfan and Kee (2013); Talavera (2005). \\
\hline 22 & Resources (R) & Delgado-Hernandez and Aspinwall (2008). \\
\hline
\end{tabular}

As stated previously, this study was used Pareto analysis for identifying a set of CSFs from 37 studies. In this method, TQM CSFs can be ranked and arranged from highest (Top of Table) to lowest frequency of occurrences in 
lower part of Table. As can be seen in Table 3, the frequency of occurrences, percent frequency, and percent cumulative frequency for each of the TQM CSFs was presented based on Pareto analysis (from highest to lowest frequency). The frequency of occurrences for each CSFs has interpreted its importance in success or failure of TQM implementation. Specially, the first few of CSFs have the essential role in implementing TQM successfully. Talib et al (2010) and Mahboob et al. (2015) called the first few TQM CSFs as "vital few CSFs that accounted for 80 percent of occurrences", and the rest of TQM CSFs (20\%) are "useful many CSFs".

In addition, data analysis of the eight empirical studies that were conducted in construction industry (Gherbal et al., 2012; Kheni and Ackon, 2015; Metri, 2005; Saeed and Hasan, 2012; Al-Otaibi et al., 2015; Al-Nasser et al., 2013; Delgado-Hernandez and Aspinwall, 2008; Koh and Low, 2010), and likewise twenty-one studies in manufacturing or/and service sector/s (Burli et al., 2012; Shafiq et al., 2014; Hassan et al., 2012; Fotopoulos et al., 2010; Malik et al., 2010; Deepa, 2014; Santos-Vijande and Alvarez-Gonzalez, 2007; Martinez-Costa et al., 2004; Martinez-Costa et al., 2008; Mahmood et al., 2015; Kaur and Sharma, 2014; Herzallah et al., 2014; Mehmood et al., 2014; Bigliardi and Galati, 2014; Prajogo and Hong, 2008; Hassan et al., 2013; Koc, 2011; Martinez-Costa et al., 2009; Kuo et al., 2009; Tan et al., 2013; Karuppusami and Gandhinathan, 2006; Alamri, et al., 2014; Zakuan et al., 2012; Talavera, 2005; Arshida and Agil, 2013; Arumugam et al., 2011; Irfan and Kee, 2013; Talib et al, 2010; Mahboob et al., 2015), revealed the ten most widely used TQM practices in developing the TQM frameworks by scholars in both construction and all industries that are accounted for 80 percent of occurrences as "vital few CSFs", which are respectively: Customer focus (CF), Leadership (L), Process Management (PM), Supplier Management (SM), Employee Involvement (EI), Information and Analysis (IA), Education and Training (ET), Continuous Quality Improvement (CQI), Strategic Quality Management (SQM), and Human Resource Management (HRM). Interestingly, the "vital few CSFs" of all empirical studies are almost similar with construction studies. While there is just a difference between the "vital few CSFs" of the studies on construction (teamwork) and all industries (continuous quality improvement). Doubtlessly, the adoption of these TQM practices are critical for improving quality performance in construction organizations, but there is an important question. Do the practitioners and scholars need to use all "vital few CSFs" for constructing an appropriate TQM model at project and enterprise levels in the construction industry?

As Parmenter (2007, p. 24) noted, the practitioners and scholars might initially be found even up to 30 CSFs that are "critical for the continued health of their organization based on the investigations. Better practice suggests that there should be only between five and eight CSFs". "Once the right CSFs determined", then the suitable indicators are easy to find for generating an effective TQM implementation frameworks. Therefore, there is no a certain number in adopting TQM practices, but it should be minimum 5 and maximum 8 TQM CSFs. In this study, the literature review reported that the empirical studies selected different numbers of TQM CSFs in their frameworks.

As shown in Table 3, the total frequency of occurrences of the 37 CSFs is about 270, which means the average of number of TQM CSFs adopted from these studies in different industries is approximately seven CSFs $(270 \div 37=7.3)$. Accordingly, these seven most frequently used CSFs can be introduced as critical practices in successful TQM implementation, which are namely: Customer focus (CF), Leadership (L), Process Management (PM), Supplier Management (SM), Employee Involvement (EI), Information and Analysis (IA), and Education and Training (ET). Amazingly, all these seven TQM CSFs are the same in bout construction and all empirical studies from different industries. This result is consistent with the opinions of Oakland (2003), Hietschold et al. (2014), DelgadoHernandez and Aspinwall (2008), and Kalpande et al. (2012), who believed there is no significant difference between TQM CSFs of construction and other industries. Furthermore, a set of appropriate TQM CSFs that this study found are provided supporting evidence for the research of Gherbal et al. (2012). They noticed and reported that "process management", "leadership", and "customer focus" are common into the frameworks of TQM implementation, while the majority of studies adopted "education and training", "supplier management", "information and analysis", "employee involvement". Likewise, these seven TQM CSFs of this study are similar with ten CSFs that recommended by Metri (2005) for developing an effective TQM framework in construction industry. 
Table 3:- Comparison of the list of CSFs-vital few ( 80 percent) and -useful many (20 percent) in construction and all industries based on Pareto analysis

\begin{tabular}{|c|c|c|c|c|c|c|c|c|}
\hline \multirow{2}{*}{ CSF } & \multicolumn{4}{|c|}{ Construction Industry } & \multirow{2}{*}{ CSF } & \multicolumn{3}{|c|}{ All Industries } \\
\hline & F. & C.C. & P.F.C. & C.P. & & F. & C.C. & P.F.C. \\
\hline $\mathbf{L}$ & 8 & 8 & 12.7 & 12.7 & $\mathbf{C F}$ & 33 & 33 & 12.22 \\
\hline SM & 7 & 15 & 11.11 & 23.81 & $\mathbf{L}$ & 32 & 65 & 11.85 \\
\hline ET & 7 & 22 & 11.11 & 34.92 & PM & 28 & 93 & 10.37 \\
\hline PM & 6 & 28 & 9.5 & 44.42 & SM & 24 & 117 & 8.89 \\
\hline EI & 6 & 34 & 9.5 & 53.92 & EI & 22 & 139 & 8.15 \\
\hline $\mathbf{C F}$ & 5 & 39 & 7.93 & 61.85 & IA & 21 & 160 & 7.78 \\
\hline IA & 5 & 44 & 7.93 & 69.8 & ET & 17 & 177 & 6.3 \\
\hline SQM & 3 & 47 & 4.7 & 74.5 & CQI & 14 & 191 & 5.19 \\
\hline $\mathbf{T}$ & 3 & 49 & 4.7 & 79.2 & HRM & 14 & 205 & 5.19 \\
\hline HRM & 3 & 53 & 4.7 & 83.9 & SQM & 13 & 218 & 4.8 \\
\hline QC & 2 & 55 & 3.17 & 87.1 & PSD & 11 & 229 & 4.07 \\
\hline PSD & 2 & 57 & 3.17 & 90.24 & $\mathbf{T}$ & 7 & 236 & 2.6 \\
\hline C & 2 & 59 & 3.17 & 93.41 & $\mathrm{C}$ & 7 & 243 & 2.6 \\
\hline CQI & 1 & 60 & 1.6 & 95.01 & $\overline{Q C}$ & 5 & 248 & 1.85 \\
\hline QS & 1 & 61 & 1.6 & 96.61 & QS & 5 & 253 & 1.85 \\
\hline $\mathbf{R R}$ & 1 & 62 & 1.6 & 98.21 & $\mathbf{R R}$ & 4 & 257 & 1.48 \\
\hline $\mathbf{R}$ & 1 & 63 & 1.6 & 100 & B & 3 & 260 & 1.11 \\
\hline RQD & 0 & 63 & 0 & 100 & RQD & 3 & 263 & 1.11 \\
\hline FBM & 0 & 63 & 0 & 100 & FBM & 2 & 265 & 0.74 \\
\hline QA & 0 & 63 & 0 & 100 & QA & 2 & 267 & 0.74 \\
\hline CQ & 0 & 63 & 0 & 100 & CQ & 2 & 269 & 0.74 \\
\hline B & 0 & 63 & 0 & 100 & $\mathbf{R}$ & 1 & 270 & 0.36 \\
\hline
\end{tabular}

\section{Conclusions:-}

The study was focused on specifying the most critical TQM practices in successful TQM implementation within construction, and other industries. However, the study examined 37 TQM models that extracted from main databases, these frameworks were developed by scholars in different industries and countries, in order to evaluate the impact of TQM and its elements on different performance indicators. From the review, the 22 CSFs of TQM revealed from these frameworks, then Pareto analysis highlighted that the only ten most frequently of CSFs were as "vital few CSFs".

The analysis of the TQM frameworks indicated that the adoption of a total of the seven most frequently cited TQM CSFs is the best way in developing a TQM framework in construction industry, and likewise there is no difference between theses CSFs in construction and other industries. As Oakland (2003), Hietschold et al. (2014), DelgadoHernandez and Aspinwall (2008), and Kalpande et al. (2012) stated that the practitioners and scholars can use the results of TQM studies in different sectors for identifying TQM CSFs. Finally, based on the results of this study the seven TQM CSFs, or enablers are proposed for TQM implementation, and further studies in construction, or even other industry as well. The practitioners or scholars can use these CSFs and link them to proper indicators, in order to understand whether the benefits of CSF's are being achieved by the organizations, as presented in Figure 2 . 


\section{Enablers}

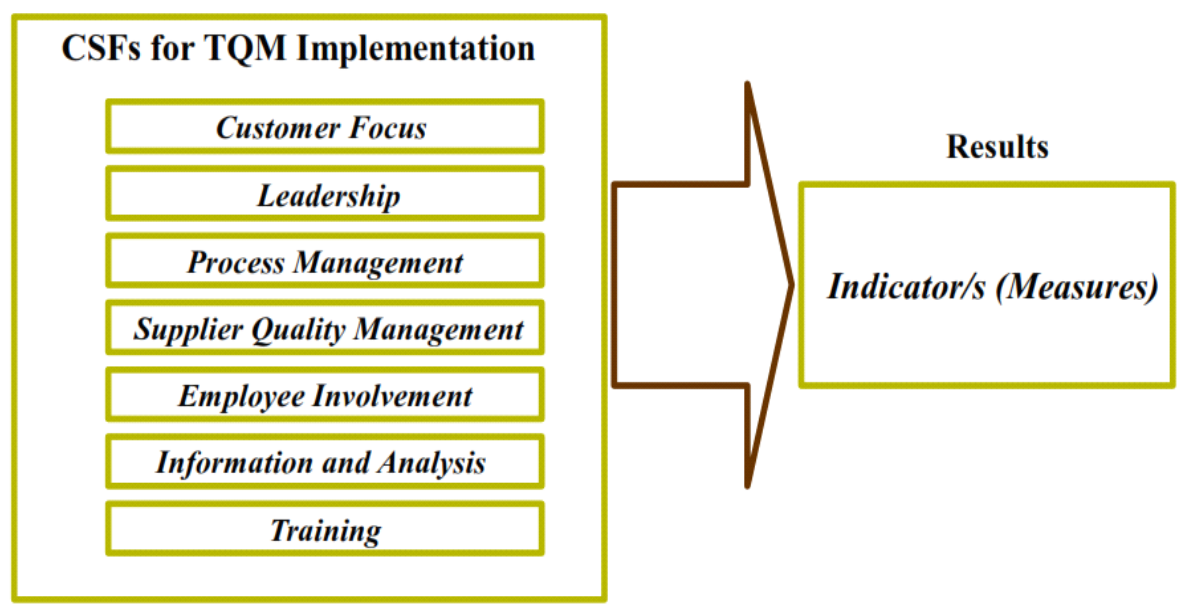

Figure 2:- A set of appropriate CSFs (Enablers) linking with indicators (Results) for successful TQM implementation in construction, and other industries.

\section{References:-}

1. Alamri, A.M., Alharthi, A.M., Alharthi, D.K., Alhabashi, W.S., \& Hasan, S.A. (2014). Organization Performance Improvement using TQM, International Journal of Computer Applications, 108(9), pp. 29-33.

2. Al-Nasser, A., Yusoff, R.Z., \& Islam, R. (2013). Relationship Between Hard Total Quality Management Practices and Organizational Performance in Municipalities, American Journal of Applied Sciences, 10 (10), PP. 1214-1223.

3. Al-Otaibi, F.M., Alharbi, M.F., \& Almeleehan, A. (2015). Effect of Total Quality Management Practices Factors on the Competitiveness: Evidence from Saudi Arabia, International Journal of Business and Management, 10(5), pp. 85-97.

4. Arshida, M.M., \& Agil, S.O. (2013). Critical Success Factors for Total Quality Management Implementation within the Libyan Iron and Steel Company, ISS \& MLB / September 24-26, 2013, pp. 254-259.

5. Arumugam, V.C., Mojtahedzadeh, R., \& Malarvizhi, C.A. (2011). Critical Success Factors of Total Quality Management and their impact on Performance of Iranian Automotive Industry, International Conference on Innovation, Management and Service, 14(2011), pp. 312-316.

6. Ashokkumar, D. (2014). Study of Quality Management in Construction Industry, International Journal of Innovative Research in Science, Engineering and Technology, 3(1), pp. 36-43.

7. Bigliardi, B., \& Galati, F. (2014). The Implementation of TQM in R\&D Environments, Journal of Technology Management \& Innovation, 9(2), pp. 157-171.

8. Burli, S.B., Kotturshettar, B.B., \& Dalmia, R.V. (2012). Multiple Performance Measures: Six TQM Practices, SCMS Journal of Indian Management, January - March, 2012, pp. 69-79.

9. Deepa, P. (2014). Evolution of Quality: A Study of Quality From Primitive Period to Latest Development in India, Journal of Management Awareness, 17(2), pp. 21-32.

10. Delgado-Hernandez, D.J., \& Aspinwall E. (2008). A framework for building quality into construction projects Part I, Journal of Total Quality Management \& Business Excellence, 19(10), pp. 1013-1028.

11. Farooqui, R.U., \& Ahmed, S.M. (2009). "ISO 9000: A Stepping Stone to Total Quality Management for Construction Companies?," In Proceedings of the Seventh Latin American and Caribbean Conference for Engineering and Technology, pp.1-9. Retrieved from http://laccei.org/LACCEI2009-Venezuela/p249.pdf. [Accessed in March 24, 2016].

12. Forbes, L H. \& Ahmed S. M. (2011). Modern construction : lean project delivery and integrated practices. Boca Raton, Fly: Taylor and Francis Group.

13. Fotopoulos, C.V., Psomas, E.L., \& Vouzas, F.K. (2010). Investigating total quality management practice's inter-relationships in ISO 9001:2000 certified organizations, Journal of Total Quality Management \& Business Excellence, 21(5), May 2010, 503-515.

14. Cheng, C.W., \& Liu, A.M. (2007). The Relationship of Organizational Culture and the Implementation of Total Quality Management in Construction Firms, ournal of Surveying and Built Environment, 18 (1), pp. 7-16. 
15. Gherbal, N., Shibani, A., Saidani, M., \& Sagoo, A. (2012). Critical Success Factors of Implementing Total Quality Management in Libyan Organizations, International Conference on Industrial Engineering and Operations Management Istanbul, Turkey, July 3-6, 2012, pp. 80-89.

16. Golob, K., Bastič, M. and Pšunder, I. (2013). "Influence of Project and Marketing Management on Delays, Penalties, and Project Quality in Slovene Organizations in the Construction Industry," Journal of Management in Engineering, 29(4), pp. 495-502.

17. Hassan, M., Mukhtar, A., Qureshi, S., \& Sharif, S. (2012). Impact of TQM Practices on Firm's Performance of Pakistan's Manufacturing Organizations, International Journal of Academic Research in Business and Social Sciences, October 2012, 2(10), pp. 232-259.

18. Hassan, M., Hassan, S., Shaukat, S., \& Nawaz, M.S. (2013). Relationship between TQM Elements and Organizational Performance: An Empirical Study of Manufacturing Sector of Pakistan, Pakistan Journal of Commerce and Social Sciences, 7 (1), pp. 01-18.

19. Herzallah, A.M., Gutierrez-Gutierrez, L., \& Rosas, J.M. (2014). TQM and financial performance: are findings of direct effects methodological artefacts? Journal of Total Quality Management \& Business Excellence, 25(6), pp. 635-649.

20. Hietschold, N., Reinhardt, R., \& Gurtner, S. (2014). Measuring critical success factors of TQM implementation successfully - a systematic literature review. International Journal of Production Research, 52( 21), pp. 62546272 .

21. Hoonakker, P., Carayon, P., \& Loushine, Todd. (2010). Barriers and benefits of quality management in the construction industry: An empirical study, Journal of Total Quality Management \& Business Excellence, 21(9), pp. 953-969.

22. Irfan, S.M., \& Kee, D.H. (2013). Critical Success Factors of TQM and its Impact on Increased Service Quality: A Case from Service Sector of Pakistan, Middle-East Journal of Scientific Research, 15(1): pp. 61-74.

23. Karuppusami, G. and Gandhinathan, R. (2006). Pareto analysis of critical success factors of total quality management: Aliterature review and analysis. TQM Magazine, 18(4), pp. 372-85.

24. Kaur, P., Sanjeev, K., \& Sharma, S.K. (2014). Evaluating the Relationship and Influence of Critical Success Factors of TQM on Business Performance: Evidence from SMEs of Manufacturing Sector, IUP Journal of Operations Management, 13(4), pp. 17-30.

25. Khattak, A.B., \& Arshad D.I. (2015). "Barricades in Implementation and Adoptation Level of ISO-9001 in Construction Industry of Pakistan," European Journal of Business and Management, 7(13), pp. 203-211.

26. Kheni, N.A., \& Ackon, F. (2015). Impact of Total Quality Management Practices (TQMPs) on Construction Project Quality Performance in Developing Countries: Study of Construction Businesses in Ghana, International Journal of Management Science, 2(3), pp. 35-51.

27. Koc, T. (2011). The Relationship Between TQM and Performance in Small Manufacturing Enterprises: The Mediation Effect of Failure, International Journal of Industrial Engineering, 18(4), pp. 203-218.

28. Koh, T.Y., \& Low, S.P. (2010). An Empiricist Framework for TQM Implementation in Construction Companies, Journal of Management in Engineering (American Society of Civil Engineers), 26(3), pp. 133-143.

29. Kuo, T., Chang, T., Hung, K., \& Lin, M. (2009). Employees' perspective on the effectiveness of ISO 9000 certification: A Total Quality Management framework, Journal of Total Quality Management \& Business Excellence, 20(12), pp. 1321-1335.

30. Lee, D.E., Lim, T.K., \& Arditi, D. (2011). "An Expert System for Auditing Quality Management Systems in Construction," Computer-Aided Civil and Infrastructure Engineering Journal, 26, pp. 612-631.

31. Mahmood, S., Qadeer, F., \& Ahmad, A. (2015). The Role of Organizational Learning in Understanding Relationship between Total Quality Management and Organizational Performance, Pakistan Journal of Commerce and Social Sciences, 9(1), pp. 282-302.

32. Mahboob, T., Tariq, B., Anwar, S., \& Khanum, M. (2015). Pareto Analysis of Critical Success Factors for Total Quality Management Targeting the Service Industry, International Journal of Computer Applications,121(14), pp. 20-24.

33. Malik, S.A., Iqbal, M.Z., Shaukat, R., \& Yong, J. (2010). TQM Practices \& Organizational Performance: Evidence From Pakistani SMEs, International Journal of Engineering \& Technology IJET-IJENS, 10(4), pp. 20-25.

34. Mane, P.P., \& Patil, J.R. (2015). "Quality Management System at Construction Project: A Questionnaire Survey," Int. Journal of Engineering Research and Applications, 5(3), pp.126-130.

35. Martinez-Costa, M., Martinez-Lorente, A.R. \& Choi, T. Y.,(2008). Simultaneous consideration of TQM and ISO 9000 on performance and motivation: An empirical study of Spanish companies, International Journal of Production Economics, 113 (2008), pp. 23-39. 
36. Martinez-Costa, M., Choi, T. Y., Martinez, J. A., \& Martinez-Lorente, A.R. (2009). ISO 9000/1994, ISO 9001/2000 and TQM: The performance debate revisited, Journal of Operations Management, 27 (2009), pp. $495-511$.

37. Martinez Lorente, A.R., \& Martinez-Costa, M. (2004), "ISO 9000 and TQM: substitutes or complementary"?, International Journal of quality and Reliability Management, 21(3), pp. 260-276.

38. Mehmood, S., Qadee, F., \& Ahmad, A. (2014). Relationship between TQM Dimensions and Organizational Performance, Pakistan Journal of Commerce and Social Sciences (Pak J Commer Soc Sci), 8 (3), pp. 662- 679.

39. Metri, B.A. (2005). TQM critical success factors for construction firms, Journal of Management, 10(2), pp. 6172.

40. Oakland, J. S. (2003). Total Quality Management: text with cases $\left(3^{\text {rd }}\right.$ ed.). Jordan Hill, Oxford, UK.

41. Prajogo, D.I., \& Hong, S.W. (2008). The effect of TQM on performance in R\&D environments: A perspective from South Korean firms, Journal of Technovation, 28 (2008), pp. 855-863.

42. Parmenter, D. (2007). Key performance indicators: developing, implementing, and using winning KPIs. Hoboken, New Jersey: John Wiley \& Sons, Inc.

43. Saeed, N.M. , \& Hasan, A.S. (2012). The Effects of Total Quality Management on Construction Project Performance: Case Study: Construction Firms in Yemen, Journal of Science \& Technology, 17(2), pp. 11-30.

44. Santos-Vijande, M.L., \& Alvarez-Gonzalez, L.I. (2007). TQM and firms performance: An EFQM excellence model research based survey, International Journal of Business Science and Applied Management, 2(2), pp. 2141.

45. Shafiq, M., Mirza, K., Abid, K., \& Naeem, M.A. (2014). "Effect of ISO 9000 Certification on TQM Implementation," Journal of Quality and Technology Management, 5(2), pp. 01-26.

46. Talavera, G.V. (2005). TQM Adoption and Firm Performance in the Philippines, Philippine Management Review, 2005(12), pp. 23-44.

47. Talib, F., Rahman, Z., \& Qureshi, M.N. (2010). Pareto Analysis of Total Quality Management Factors Critical to Success for Service Industries, International Journal for Quality research, 4(2), pp. 155-168.

48. Tan, B.I., Wong, K.L., \& Choong, C.K. (2013). TQM and Family Owned Business: Performance and Sustainability, Proceedings of of 2013 International Conference on Technology Innovation and Industrial Management, 29-31 May 2013, Phuket, Thailand.

49. Walliman, N. (2011). Research Methods the Basic. Abingdon, Oxon: Routledge from Taylor \& Francis Group.

50. Zakuan, M., Muniandy, S., Saman, M.Z., Ariff, M.S., Sulaiman, S., \& Jalil, R. A. (2012). Critical Success Factors of Total Quality Management Implementation In Higher Education Institution: A Review, International Journal of Academic Research in Business and Social Sciences, 2(12), pp. 19-32. 